\title{
FORCE MAJEURE AND HARDSHIP IN INTERNATIONAL SALES CONTRACTS
}

\author{
Ingeborg Schwenzer*
}

This article takes an analytical look of the concepts of force majeure and hardship when attempting to extract oneself from an agreement. The article starts off with a brief summary of their historical background and their presence in various domestic legal systems, such as France, Germany and the Netherlands. It goes on to examine the Convention on the International Sale of Goods (CISG) which does not have force majeure and hardship provisions but does have a provision that has the same effect. The article goes on to describe the requirements for avoiding liability in international sales contracts and concludes with the consequences of force majeure and hardship.

It is a great honour to be invited to contribute to this tribute issue for Tony Angelo. Tony has always been a wanderer between countries and continents fructifying legal thinking across borders. This small paper cannot even pretend to have such importance. It will simply discuss some current questions that we face in international sales law.

\section{INTRODUCTION}

Unforeseeable changed circumstances are probably one of the major problems parties especially those who are party to a long or longer term complex contract - may face in international trade. Indeed, with globalisation these problems are increased as the involvement of more and more countries in production and procurement entails even greater imponderables. Natural disasters or changes of political and economic factors may considerably affect the very basis of the bargain. There may be an earthquake, a flood or a civil war in one of the production countries, forcing the producer to resort to countries with much higher production costs; import or export bans may hinder the envisaged flow of goods; or price fluctuations that were not foreseeable at the time of the conclusion of the contract make the performance by the seller unduly burdensome or devaluate the contract performance for the buyer.

The paradigm of pacta sunt servanda or sanctity of contract simply places the burden of such a change of circumstances upon the party on which it falls. However, since the old Roman days the

* Dr iur (Freiburg i Br), LLM (UC Berkeley), Professor of Private Law at the University of Basel, Switzerland. I am deeply indebted to my research assistant, lic iur Alain F Hosang, for editing the footnotes. 
principle of impossibilium nulla est obligatio, or there is no obligation to perform impossible things, ${ }^{1}$ has been recognised. Things were simple at that time: the slave or the cattle that had been sold had perished; or perhaps the crop that should be delivered was destroyed. Furthermore, under the doctrine of rebus sic stantibus ${ }^{2}$ developed by the Roman praetor, ${ }^{3}$ an unforeseeable and extraordinary change of circumstances rendering a contractual obligation extremely burdensome could be recognised. Since these days, impossibility, force majeure or the like have become grounds for exemption in every legal system. ${ }^{4}$ However, the question whether simple changes in the surrounding economic conditions may exempt the debtor from liability under the contract has always been a hotly debated issue. ${ }^{5}$ It is to this very day. Let me first start with a short overview of how some domestic legal systems treat this question.

\section{SOME DOMESTIC SOLUTIONS}

The position of French law represents one extreme and it is well documented. Whereas the rule for force majeure is laid down in Article 1148 of the Code Civil (CC), neither general civil law nor commercial law has been favourable to the concept of hardship. ${ }^{6}$ The famous theory of imprévision $^{7}$ that allows a contract to be modified in case of a change of circumstances has been applied to administrative contracts only. ${ }^{8}$ However, the Cour de Cassation has apparently moved

1 Dig 50.17.185.

2 The term rebus sic stantibus was mentioned for the first time in the early $16^{\text {th }}$ century. In 1507 , Jason de Mayno (1435-1519) suggested the use of the rebus sic stantibus doctrine as a general principle in contract law. For further details on this matter see Ralf Köbler Die "clausula rebus sic stantibus" als allgemeiner Rechtsgrundsatz (JCB Mohr, Tübingen, 1991) 30-31.

3 The idea of adapting agreements and promises to an unforeseeable and extraordinary change has its roots in roman philosophy with Cicero and Seneca. The doctrine found its way into the Canon law in the $14^{\text {th }}$ century, referring to it as rebus sic se habentibus. For further details see Köbler, above n 2, 28.

4 See Germany: Bügerliches Gesetzbuch (BGB) § 313 (Störung der Geschäftsgrundlage); Italy: Codice Civile (CC), Arts 1467-1469 (eccessiva onerosità sopravvenuta); France: Code Civil (CC), Art 1148 (force majeure). See also Konrad Zweigert and Hein Kötz Einführung in die Rechtsvergleichung (3ed, JCB Mohr, Tübingen, 1996) 533.

5 See Zweigert and Kötz, above n 4, 534-535. The actual trigger for this discussion was the enormous rise in prices due to World War I (1914-1918).

6 See Catherine Kessedjian "Competing Approaches to Force Majeure and Hardship" (2005) 25 Int'l Rev L \& Econ 415, 427.

7 For details, see Phillippe Stoffel-Munck Regards sur la théorie de l'imprévision: vers une souplesse contractuelle en droit privé français contemporain (Presses universitaires d'Aix-Marseille, Aix-enProvence, 1994).

8 See Conseil d'Etat, 30 Mar 1916, DP1916, 325; Piet Abas Rebus sic stantibus (Karl Heymanns, Cologne, 1993) 43. 
away slightly from the strict pacta sunt servanda principle; it appears to be heading in the direction of eventually recognising some kind of hardship. ${ }^{9}$

Many continental legal systems, however, accept the theory of hardship, among them Germany, The Netherlands, Italy, Greece, Portugal, Austria as well as the Scandinavian countries. ${ }^{10}$ The most recent acknowledgement by statute can be found in Germany. The Statute on the Modernisation of the Law of Obligations in 2001 finally codified the right to have the contract adapted to the changed circumstances in section 313 of the Bürgerliches Gesetzbuch (BGB). ${ }^{11}$

English law seems to reject any notion of relief for changed circumstances that do not amount to impossibility. ${ }^{12}$ However, in case of frustration of contract - that means where the contract is rendered useless by the change of circumstances - an exception is granted to this general rule. ${ }^{13}$ In the United States, the Uniform Commercial Code has enacted the general doctrine of impracticability. ${ }^{14}$

9 See Philippe Malaurie and Laurent Aynès Droit Civil: Les obligations (3ed, Editions juridiques associées, Paris, 2007) 379-380, stating that the judge cannot alter the contract directly on his or her own unless the parties have agreed upon a clause de sauvegarde (hardship clause) or the law itself provides for the possibility of the judicial adjustment of the contract. However, the judge is entitled to apply the principle of good faith according to Article 1134(3) CC if there is a severe inequity and one party is acting in bad faith. See also Kessedjian, above n 6, 425.

10 Germany: BGB § 313 (Störung der Geschäftsgrundlage); Netherlands: Dutch Civil Code (BW) Art 6:258; Italy: CC, Art 1467 (eccessiva onerosità sopravvenuta); Greece: Greek Civil Code, Art 388; Portugal: Portuguese Civil Code, Art 437; Austria: Austrian BGB §§ 936, 1052, 1170a through analogy; Scandinavia: see Commission on European Contract Law Principles of European Contract Law (Kluwer International Law, the Hague, Netherlands, 1999) Article 6:111, Comment note 1, 328 [Principles of European Contract Law]; see also Ole Lando "CISG and Its Followers: A Proposal to Adopt Some International Principles of Contract Law" (2005) 53 Am J Comp L 379, 397.

11 See Hannes Unberath in Heinz Georg Bamberger and Herbert Roth (eds) Kommmentar zum Bürgerlichen Gesetzbuch (2 ed, CH Beck, Munich, 2007) BGB $\S 313$ paras 1-7. For the prerequisites concerning the adaptation to changed circumstances, see paras 25-84.

12 In Common Law systems, "hardship" seems to be a mere term describing a fact and not a judicial concept. See Joseph M Perillo "Hardship and its Impact on Contractual Obligations: A Comparative Analysis" (Saggi, Conferenze e Seminari, No 20, April 1996) 3; A H Puelinckx "Frustration, Hardship, Force Majeure, Imprévision, Wegfall der Geschäftsgrundlage, Unmöglichkeit, Changed Circumstances" (1986) 3 J Int'l Arb 47, 64.

13 See Guenter Treitel Frustration and Force Majeure (2 ed, Sweet \& Maxwell, London, 2004) 314. The frustration of purpose doctrine amounts to the discharge of the contract: see Ewan McKendrick "Discharge by Frustration" in AG Guest (ed) Chitty on Contracts, Vol I: General Principles (30ed, Sweet \& Maxwell, London, 2008) paras 23-001-23-006.

14 UCC § 2-615. The Restatement Second, Contracts 2d, reiterates this position: see American Law Institute Restatement on the Law of Contracts (2ed, American Law Institute Publishers, St Paul, Minnesota, 1981) § 261 


\section{INTERNATIONAL APPROACHES}

The Principles on International Commercial Contracts (PICC 2004), ${ }^{15}$ the Principles on European Contract Law (PECL 1999) ${ }^{16}$ as well as the Draft of a Common Frame of Reference (DCFR 2008) ${ }^{17}$ expressly provide for rules in case of a change of circumstances. In 2003, the International Chamber of Commerce (ICC) published model clauses on force majeure and hardship.

The Convention on the International Sale of Goods (CISG), however, does not contain a special provision dealing with questions of hardship. It does not mention either force majeure or hardship. ${ }^{18}$ Article 79 of the CISG relieves a party from paying damages only if the breach of contract was due to an impediment beyond its control. ${ }^{19}$ The drafting history of this provision is not quite clear. During the preparations of the CISG, the question of whether economic difficulties should give rise to an exemption was a highly controversial one. ${ }^{20}$ At the Vienna Conference, a proposal made by the Norwegian delegation aimed at releasing the debtor from its obligation if, after the cessation of a temporary impediment, there had been a radical change in the underlying circumstances was rejected. ${ }^{21}$ Thus, it is quite understandable that during the first years after the

15 See International Institute for the Unification of Private Law Principles of International Commercial Contracts (UNIDROIT, Rome, 2004) Article 6.2.3 [Principles of International Commercial Contracts].

16 Principles of European Contract Law, above n 10, Article 6:111.

17 See Study Group on a European Civil Code Draft Common Frame of Reference (Sellier, Munich, 2008) Article III - 1:110 [Draft Common Frame of Reference].

18 See Ingeborg Schwenzer in Peter Schlechtriem and Ingeborg Schwenzer (eds) Kommentar zum einheitlichen UN Kaufrecht CISG (5 ed, CH Beck, Munich, 2008) Article 79 para 4; Denis Tallon in Cesare Bianca and Michael Bonell (eds) Commentary on the International Sales Law: The 1980 Vienna Convention (Giuffrè, Milan, 1987) Article 79 para 1.3, United Nations Convention on Contracts for the International Sale of Goods (11 April 1980) A/CONF. 97/18; 1489 UNTS 3, 59 [CISG].

19 See John Honnold Uniform Law for International Sales (3ed, Kluwer Law International, The Hague, 1999) Article 79 para 423.4; Tallon in Bianca and Bonell (eds), above n 18, Article 79 para 2.6.2; WilhelmAlbrecht Achilles Kommentar zum UN-Kaufrechtsübereinkommen (CISG) (Hermann Luchterhand, Berlin, 2000) Article 79 para 3; Hanns-Christian Salger in Wolfgang Witz, Hanns-Christian Salger and Manuel Lorenz (eds) International Einheitliches Kaufrecht: Praktiker-Kommentar und Vertragsgestaltung zum CISG (Recht und Wirtschaft, Heidelberg, 2000) Article 79 para 4; Christoph Brunner Force Majeure and Hardship Under General Contract Principles: Exemption of Non-Performance in International Arbitration (Kluwer Law International, The Hague, 2009) 167.

20 See John Honnold Documentary History of the Uniform Law for International Sales: The studies, deliberations and decisions that led to the 1980 United Nations Convention with introductions and explanations (Kluwer Law and Taxation Publishers, Deventer, Netherlands, 1989) 602. See also Peter Schlechtriem Internationales UN-Kaufrecht (4ed, Mohr Siebeck, Tübingen, 2007) para 288; Brunner, above n 19, 216; Tallon in Bianca and Bonell (eds), above n 18, Article 79 para 2.6.7.

21 The Norwegian delegation proposed that paragraph 3 of Article 65 of the 1978 UNCITRAL Draft Convention should be changed in the following way: "[...] Nevertheless, the party who fails to perform is permanently exempted to the extent that, after the impediment is removed, the circumstances are so radically changed that it would be manifestly unreasonable to hold him liable" (emphasis added). See the 
coming into force of the CISG some scholars argued that there was no room to consider hardship under Article 79. ${ }^{22}$

Today, however, it is more or less unanimously accepted in court and arbitral decisions, ${ }^{23}$ as well as in scholarly writing, ${ }^{24}$ that Article 79 does indeed cover issues relating to hardship. Accordingly, first and foremost, there is no room to resort to domestic concepts of hardship ${ }^{25}$ as there is no gap in the CISG regarding the debtor's invocation of economic impossibility and the adaptation of the contract to changed circumstances. If one were to hold otherwise, unification of the law of sales would be undermined in a very important area. Domestic concepts such as frustration of purpose, rebus sic stantibus, fundamental mistake or Wegfall der Geschäftsgrundlage would all have to be considered.

However, which cases of hardship amount to an impediment under Article 79 and what remedies the aggrieved party may resort to are still matters of dispute.

\section{PREREQUISITES FOR FORCE MAJEURE AND HARDSHIP UNDER THE CISG}

\section{A General}

Article 79(1) provides that a party is exempted from liability for damages only if the failure to perform is due, first, to an impediment beyond its control and, second, that it could not reasonably

Norwegian proposal (A/CONF.97/C.1/L.191/Rev.1) in United Nations Conference on Contracts for the International Sales of Goods, Vienna, 10 March-11 April 1980 (Official Records, New York, 1981) 381.

22 See Hans Stoll in Peter Schlechtriem (ed) Commentary on the UN Convention on the International Sale of Goods (2ed, Clarendon Press, Oxford, 1998) Article 79 para 39.

23 However, the courts often decided that the equilibrium of the contract was not fundamentally altered. Therefore, the alleged impediment was non-existent. See Bulgarian Chamber of Commerce and Industry, 12 Feb 1998, CISG-online Case No 436; Rechtbank van Koophandel, Hasselt, 2 May 1995, CISG-online Case No 371; Tribunale Civile di Monza, 29 Mar 1993, CISG-online Case No 102; Cour d'Appel de Colmar, 12 Jun 2001, CISG-online Case No 694. These decisions can be found by searching the case number on the CISG-online website at www.globalsaleslaw.org.

24 See CISG AC Opinion No 7 Exemption of Liability for Damages Under Article 79 of the CISG (Rapporteur: Professor Alejandro Garro) 12 Oct 2007, Opinion 3.1 [CISG AC Opinion No 7]; Schwenzer in Schlechtriem and Schwenzer (eds), above n 18, Article 79 para 4; Niklas Lindström "Changed Circumstances and Hardship in the International Sale of Goods" (2006) (Issue 1) Nordic Journal of Commercial Law 23-24; Brunner, above n 19, 218; Schlechtriem, above n 20, para 291.

25 See Honnold, above n 19, Article 79 paras 425 and 432.2; Tallon in Bianca and Bonell (eds), above n 18, Article 79 para 3.1.2.; Schwenzer in Schlechtriem and Schwenzer (eds), above n 18, Article 79 para 12; Joern Rimke "Force Majeure and Hardship: Application in International Trade Practice with Specific Regard to the CISG and the UNIDROIT Principles of International Commercial Contracts" in Pace International Law Review (ed) Review of the Convention on Contracts for the International Sale of Goods (CISG) 1999-2000 (Kluwer, The Hague, 2001) 197, 219. 
be expected to have taken the impediment into account at the time of the conclusion of the contract or, third, to have avoided or overcome it or its consequences. ${ }^{26}$ Article 7.1.7(1) of the PICC 2004, Article 8:808(1) of the PECL 1999 as well as Article III - 3:104(1) of the DCFR 2008 are practically identical to Article 79(1). The same holds true for the ICC's Force Majeure Clause. However, the latter gives a list of events that may amount to an impediment, such as war, natural disasters, explosions, strikes, acts of authority. Thus, concerning the issue of force majeure, there are three clearly distinct prerequisites: the impediment must not fall in the sphere of risk of the obligor; it must have been unforeseeable; and, it or its consequences must have been unavoidable. ${ }^{27}$

As far as the provisions regarding hardship are concerned, again the international solutions bear great resemblance to one another. ${ }^{28}$ In the first place, the relevant articles and clauses emphasise the principle of pacta sunt servanda. ${ }^{29}$ The mere fact that performance has been rendered more onerous than could reasonably have been anticipated at the time of the conclusion of the contract does not exempt the obligor from performing the contract. ${ }^{30}$ Hardship can only be found if the performance of the contract has become excessively onerous ${ }^{31}$ or, in other words, if the equilibrium of the

26 See Hans Stoll and Georg Gruber in Peter Schlechtriem and Ingeborg Schwenzer (eds) Commentary on the UN Convention on the International Sale of Goods (2 English ed, Oxford University Press, Oxford, 2005) Article 79 paras 10-24; Peter Mankowski in Karsten Schmidt (ed) Münchener Kommentar zum Handelsgesetzbuch (CH Beck, Munich, 2004) Article 79 CISG para 17.; Schlechtriem, above n 20, para 289.

27 See Stoll and Gruber in Schlechtriem and Schwenzer (eds), above n 26, Article 79 paras 10-24; Tallon in Bianca and Bonell (eds), above n 18, Article 79 para 2.6.; Honnold, above n 19, Article 79 para 423.4; Brunner, above n 19, 111-113.

28 See Part III International Approaches.

29 Principles of International Commercial Contracts, above n 15, Article 6.2.1; Principles of European Contract Law, above n 10, Article 6:111(1); Draft Common Frame of Reference, above n 17, Article III 1:110; ICC Hardship Clause 2003 para 1. See also Rimke, above n 25, 237.

30 See Schwenzer in Schlechtriem and Schwenzer (eds), above n 18, Article 79 para 14. See also Rimke, above n 25, 197, 200; Schlechtriem, above n 20, para 291.

31 Principles of European Contract Law, above n 10, Article 6:111(2); Draft Common Frame of Reference, above n 17, Article III - 1:110(2); ICC Hardship Clause 2003 para. 2(a). See also Peter Schlechtriem Uniform Sales Law: The UN-Convention on the International Sale of Goods (Manz, Vienna, 1986) 102; Ulrich Magnus in J von Staudingers Kommentar zum Bürgerlichen Gesetzbuch mit Einführungsgesetzen und Nebengesetzen, Wiener UN-Kaufrecht (CISG) (15 ed, Sellier, Berlin, 2006) Article 79 para 4; Dietrich Maskow in Fritz Enderlein, Dietrich Maskow and Heinz Strohbach (eds) Internationales Kaufrecht (Haufe, Berlin, 1991) Article 79 para 6.3; Joseph Perillo "Force Majeure and Hardship Under the UNIDROIT Principles of International Commercial Contracts" (1996) 5 Tul J Int'l \& Comp L 1, 9; Jennifer Bund "Force Majeure Clauses: Drafting Advice for the CISG Practicioner" (1998) $17 \mathrm{~J}$ L \& Com 381, 389; Bernard Audit La vente internationale de marchandises, Convention des Nations-Unies du 11 avril 1980 (LGDJ, Paris, 1990) 174; Vincent Heuzé La vente internationale de marchandises, Droit uniforme (LGDJ, Paris, 2000) 425. 
contract has been fundamentally altered. ${ }^{32}$ Again, as in the force majeure provisions, the event in question must not fall in the sphere of risk of the aggrieved party; it must have been unforeseeable as well as unavoidable. Thus, hardship can be considered as a special group of cases under the general force majeure provisions. All that is added to the force majeure provisions on the level of prerequisites is a clarification of the term impediment in cases where performance in the strict sense is possible but just too onerous. This may justify dealing with hardship under the CISG as well as under the other international harmonisation projects in a consolidated manner.

\section{B Relevant Threshold for Hardship}

The crucial point in the first place is to determine the threshold of hardship. When has performance become excessively onerous? When has the equilibrium of the contract been fundamentally altered? Thereby, either an increase in cost of performance or a decrease in value of the performance received may be relevant. ${ }^{33}$ This means that the aggrieved party can be either the seller or the buyer.

The starting point has to be the contract itself. Primarily, it is up to the parties to define their respective spheres of risk in the contract. ${ }^{34}$ One party may have expressly or impliedly assumed the risk for a fundamental change of circumstances or, on the contrary, certain risks may have been expressly or impliedly excluded. ${ }^{35}$ This determination can be done by simple contract interpretation.

If, for example, the contract is highly speculative, the obligor can be presumed to have assumed the risk involved in the transaction. ${ }^{36}$ Thus, a German court of second instance ${ }^{37}$ did not exempt a seller from liability under Article 79 of the CISG although the market price for the contract item, iron molybdenum from China, had risen by 300 per cent. The court reasoned that in a trade sector with highly speculative traits the threshold for allowing hardship should be raised. As such, typical

32 Principles of International Commercial Contracts, above n 15, Article 6.2.2.

33 See Brunner, above n 19, 221-223.

34 See Bulgarian Chamber of Commerce and Industry, 12 Feb 1998, CISG-online 436; Avery Katz "Remedies for Breach of Contract under the CISG" (2006) 25 Int'l Rev L \& Econ 378, 381. It is also believed that the risk allocation is dependent on the parties' choice of law at the beginning: see Neil Gary Oberman Transfer of risk from seller to buyer in international commercial contracts: A comparative analysis of risk allocation under the CISG, UCC and Incoterms (LLM Thesis, Université de Montréal, 1997).

35 See Brunner, above n 19, 147-148; Treitel, above n 13, 455; Katz, above n 34, 391; CISG AC Opinion No 7, above n 24, Comment para 39.

36 Brunner, above n 19, 220; ICC Award, 26 Aug 1989, No 6281, CISG-online 8; Rechtbank van Koophandel, Tongeren, 25 Jan 2005, No 1960, CISG-online 1106.

37 See Oberlandesgericht Hamburg, 28 Feb 1997, No 167, CISG-online 261. 
fluctuations of price in the commodity trade generally will not give rise to an acknowledgement of hardship. ${ }^{38}$

It is questionable how the relevant threshold for giving rise to a hardship excuse is determined if no such special circumstances exist. Whereas the Comment to Article 6.2.2 of the PICC ${ }^{39}$ in its first edition of 1994 suggested that an alteration amounting to 50 per cent or more would likely amount to a "fundamental" alteration, the second edition of the PICC in 2004 refrains from recommending any exact figure.

Certainly, in ascertaining whether any alteration amounts to hardship, primary consideration is to be given to the circumstances of the individual case. Thus, it may be relevant whether we are dealing with a short term sales contract or a long term instalment contract. ${ }^{40}$ The profit margin in the respective trade sector may also play an important role. Finally, in cases where the financial ruin of the obligor is imminent, the threshold for allowing hardship may be lowered. ${ }^{41}$

However, legal certainty clearly calls for some benchmark. Relying on a thorough comparative analysis of domestic solutions, one author ${ }^{42}$ has suggested that, as a general rule of thumb in standard situations, a threshold of 100 per cent should be favoured. However, courts interpreting Article 79(1) CISG have been very reluctant to allow hardship in case of fluctuations of prices. ${ }^{43}$ Up to now, there is no single reported court or arbitral decision exempting a party - either a seller or a buyer - from liability under a CISG sales contract due to hardship. All decisions dealing with hardship under Article 79 concluded that even a price increase or decrease of more than 100 per cent would not suffice. ${ }^{44}$ The suggested "100 per cent threshold" seems to be based upon considerations of domestic markets where price fluctuations are not to be expected to the same degree as in

38 See Benjamin Leisinger Fundamental Breach Considering Non-Conformity of the Goods (Sellier, Munich, 2007) 119.

39 Principles of International Commercial Contracts, above n 15, comment 2.

40 Brunner, above n 19, 438-441.

41 Ibid, 438-439.

42 Ibid, 428-435; Christoph Brunner UN-Kaufrecht - CISG, Kommentar zum Übereinkommen der Vereinten Nationen über Verträge über den internationalen Warenkauf von 1980, unter Berücksichtigung der Schnittstellen zum internen Schweizer Recht (Stämpfli, Bern, 2004) Article 79 CISG para 26.

43 See ICC Award, 26 Aug 1989, No 6281, CISG-online 8; Tribunale di Monza, 14 Jan 1993, CISG-online 540; Joseph Lookovsky "Impediments and Hardship in International Sales: A Commentary on Catherine Kessedjian's 'Competing Approaches to Force Majeure and Hardship'" (2005) 25 Int'l Rev L \& Econ 434, 438.

44 It is argued that an increased price is foreseeable for a company involved in international trade. See CIETAC, 10 May 1996, No 21, CISG-online 1067; Bulgarian Chamber of Commerce and Industry, 12 Feb 1998, No 11, CISG-online 436; Rechtbank van Koophandel, Hasselt, 23 Feb 1994, No 1849, CISG-online 371; Cour d'Appel de Colmar, 12 Jun 2001, CISG-online 694; Cour de Cassation, 30 Jun 2004, No 964, CISG-online 870. 
international markets. In an international market, one may expect the potentially aggrieved party to insist on incorporating terms for a possible adjustment in the contract or otherwise assuming the risk for higher fluctuations than usually occur on domestic markets. Thus, the margin certainly has to be set at a higher point. A 150-200 per cent margin seems to be advisable.

\section{Time Factor}

In cases of force majeure, it is more or less unanimously held that it is irrelevant whether the impediment arose after the conclusion of the contract or if it already existed at the time of conclusion. ${ }^{45}$ Thus, if the goods sold had already been destroyed at the time of the conclusion of the contract, but the seller did not know about nor could have prevented this fact, the seller may be exempted under Article 79(1) of the CISG. ${ }^{46}$

In cases of hardship, however, it is argued that the changed circumstances must have occurred after the conclusion of the contract. ${ }^{47}$ This is the position taken by domestic legal systems. ${ }^{48}$ Similarly, the wording of Article 6:111(1) of the PECL $1999^{49}$ is clearly based upon this assumption. The related Comment affirms this position. ${ }^{50}$ However, although the wording of Article 6.2.1 of the PICC $2004^{51}$ seems to point in the same direction, Article 6.2.2(a) of the PICC 2004 clarifies that hardship may be found if either the events that are causing the imbalance of the

45 See Stoll and Gruber in Schlechtriem and Schwenzer (eds), above n 26, Article 79 para 12; Rolf Herber and Beate Czerwenka Internationales Kaufrecht, Kommentar zu dem Übereinkommen der Vereinten Nationen vom 11. April 1980 über Verträge über den internationalen Warenkauf (CH Beck, Munich, 1991) Article 79 para 11; United Nations Secretariat "Commentary on the Draft Convention on Contracts for the International Sale of Goods prepared by the Secretariat" (14 March 1979) A/CONF 97/5, OR 14, Article 65 para 4; Karl H Neumayer and Catherine Ming in Francois Dessemontet (ed) Convention de Vienne sur les contrats de vente internationale de marchandises: commentaire (CEDIDAC, Lausanne, 1993) Article 79 para 6; disapproving Tallon in Bianca and Bonell (eds), above n 18, Article 79 note 2.4.3.

46 See Stoll and Gruber in Schlechtriem and Schwenzer (eds), above n 26, Article 79 para 12; CISG AC Opinion No 7, above n 24, Comment para 8.

47 See Stoll and Gruber in Schlechtriem and Schwenzer (eds), above n 26, Article 79 para 12; Principles of International Commercial Contracts, above n 15, Article 6.2.2, Comment No 3a; Brunner, above n 19, 398399.

48 See BGB § 313(1): "Haben sich die Umstände [...] nach Vertragsschluss schwerwiegend verändert ..." (emphasis added).

49 See Principles of European Contract Law, Article 6:111(1): "... if performance has become more onerous ..." (emphasis added). See also Draft Common Frame of Reference, above n 18, Article III - 1:110(2).

50 See Principles of European Contract Law, Article 6:111, Comment B (ii).

51 See Principles of International Commercial Contracts, Article 6.2.1: "Where the performance ... becomes more onerous ..." (emphasis added). 
performances occur or if they become known to the disadvantaged party after the conclusion of the contract. ${ }^{52}$

To date, neither case law nor scholarly writing has discussed the relevant time factor under the CISG - assuming one accepts hardship as being covered by Article 79. In order to decide whether an initial gross imbalance between the performances of the parties, due to circumstances neither known to the parties nor preventable, may amount to hardship under Article 79, one has to consider what other remedies the aggrieved party could rely on when discovering that, already at the time of the conclusion of the contract, there had been a gross disparity between the respective values of the agreed upon performances. Most likely under domestic laws as well as under PECL 1999, initial gross disparity between the parties' performances will give rise to remedies for mistake. ${ }^{53}$ These coexisting remedies may be tolerated within one single legal system; difficult problems, however, can arise when dealing with sales contracts under the CISG. ${ }^{54}$ As the CISG does not contain any provisions on mistake, this question would have to be resolved relying on the otherwise applicable domestic law. ${ }^{55}$ However, this may well lead to unpredictable results. For example, it might be questionable at what point in time production costs have risen, be it before the conclusion of the contract or only afterwards. Furthermore, uniformity in such an important area of sales law would be endangered by applying domestic rules on mistake to this question. It is exactly these considerations that, in the case of force majeure, compel the same treatment for initial and subsequent impediments. Thus, if the goods have been destroyed the time of the conclusion of the contract, domestic rules declaring such a contract as being void are excluded. ${ }^{56}$ Nothing else, however, can apply in cases of hardship. Thus, the very term of hardship under the CISG should be interpreted and understood in the broadest sense, encompassing any change of circumstances after

52 The ICC Hardship Clause 2003 seems to be open for interpretation.

53 See Principles of European Contract Law, above n 10, Article 6:111, Comment B (ii). For the Netherlands see M M van Rossum "Validity" in Daniel Busch and others (eds) The Principles of European Contract Law and Dutch Law. A Commentary (Kluwer Law, The Hague, 2002) 193; Restatement on the Law of Contracts, above n 14, § 266 ("Existing Impracticability or Frustration").

54 See Patrick C Leyens "CISG and Mistake, Uniform Law vs Domestic Law: The Interpretative Challenge of Mistake and the Validity Loophole" in Pace International Law Review (ed) Review of the Convention on Contracts for the International Sale of Goods (CISG) 2002-2003 (Sellier, Munich, 2005) 3, 15.

55 It is argued that a party can rely on mistake where the CISG and the domestic law provide the same remedies. For a detailed discussion about this matter see Leyens, above n 54, 34; Stefan Kröll "Selected Problems Concerning the CISG's Scope of Application" (2005) 25 J L \& Com 39, 55.

56 See Stoll and Gruber in Schlechtriem and Schwenzer (eds), above n 26, Article 79 para 12; Nicholas in Bianca and Bonell (eds), above n 18, Article 68 para 3.1; Magnus in Staudinger, above n 31, Article 4 para 44 and Article 79 para 33; Kurt Siehr in Heinrich Honsell (ed) Kommentar zum UN-Kaufrecht (Springer, Berlin, 1997) Article 4 paras 5 and 15; Brunner, above n 42, Article 4 para 9; Maskow in Enderlein, Maskow and Strohbach (eds), above n 31, Article 79 para 5.2; but see Tallon in Bianca and Bonell (eds), above n 18, Article 79 para 2.4.3. 
the conclusion of the contract as well as a gross disparity of the value of performances already existing at the time of conclusion of the contract.

\section{Events that Could not Reasonably be Taken into Account or Avoided or Overcome}

Force majeure as well as hardship can only exempt the aggrieved party from liability if the events causing the impediment could not reasonably be taken into account by the aggrieved party at the time of the conclusion of the contract. ${ }^{57}$ If they could have been taken into account by the aggrieved party, then it can be expected that this party would insist on incorporating a specific contract clause to deal with the problem. Thus, this party must be assumed to have taken the risk. ${ }^{58}$

Furthermore, even an impediment that the aggrieved party could not foresee at the time of the conclusion of the contract does not exempt it if overcoming the impediment is both possible and reasonable. ${ }^{59}$ Whether the obligor can be expected to overcome the impediment has to be decided by taking the above mentioned threshold for hardship into account. ${ }^{60}$ Thus, for example, the seller must turn to another supplier or consider alternative possibilities for the transportation of the goods if the increase in costs does not exceed the relevant threshold.

\section{CONSEQUENCES OF FORCE MAJEURE AND HARDSHIP}

\section{A Exemption from Liability}

If the non-performance is due to an impediment that fulfils the conditions set forth in Article 79(1) of the CISG or comparable provisions, ${ }^{61}$ first and foremost, the obligor is relieved from its obligation to pay damages. ${ }^{62}$ This includes so-called "liquidated damages" 63 as well as penalties (if

57 See Stoll and Gruber in Schlechtriem and Schwenzer (eds), above n 26, Article 79 para 22; Tallon in Bianca and Bonell (eds), above n 18, Article 79 para 2.6.3; Salger in Witz, Salger and Lorenz (eds), above n 19, Article 79 para 5; Magnus in Staudinger, above n 31, Article 79 para 32.

58 See Stoll and Gruber in Schlechtriem and Schwenzer (eds), above n 26, Article 79 para 22; Audit, above n 31, 174; Tallon in Bianca and Bonell (eds), above n 18, Article 79 para 2.6.3.; Neumayer and Ming, above $n$ 45, Article 79 para 4.

59 See Stoll and Gruber in Schlechtriem and Schwenzer (eds), above n 26, Article 79 para 23; Honnold, above n 19, Article 79 para 432.1; Brunner, above n 19, 322; Magnus in Staudinger, above n 31, Article 79 para 34.

60 See above IV Prerequisites for Force Majeure and Hardship Under the CISG.

61 See Principles of International Commercial Contracts, above n 15, Article 7.1.1; Principles of European Contract Law, above n 10, Article 8:108; Draft Common Frame of Reference, above n 17, Article III 3:104.

62 See Stoll and Gruber in Schlechtriem and Schwenzer (eds), above n 26, Article 79 para 43; Maskow in Enderlein, Maskow and Strohbach (eds), above n 31, note 4 to part IV: Befreiungen; Honnold, above n 19, Article 79 para 423.4; Brunner, above n 19, 345, 346.

63 See McKendrick "Discharge by Frustration" in A G Guest (ed) Chitty on Contracts, above n 13, para 26010; John D Calamari and Joseph M Perillo The Law of Contracts (5ed, Thomson West, St Paul, 2003) 611- 
they are at all valid under the governing domestic law), unless the parties have provided otherwise in their contract. ${ }^{64}$

Article 8:101(2) of the PECL 1999 clearly states that where a party's non-performance is excused, alongside with the right to claim damages, the right to performance is likewise excluded. ${ }^{65}$ Whether the exemption under Article 79 of the CISG also extends to the promisee's right of performance has been a subject of considerable debate ${ }^{66}$ because of the somewhat misleading wording of Article 79(5). ${ }^{67}$ It should be noted that, at the Vienna Conference, a German proposal that the wording should make it clear that if the impediment were a continuing one performance could not be insisted on was rejected. It was held that, in the case of actual impossibility, no problems would arise in practice whereas the categorical removal of the right to performance could impair the promisee's accessory rights. ${ }^{68}$ Although, especially among German authors, there still remain doubts about the doctrinal justification, ${ }^{69}$ nowadays it seems to be undisputed that, wherever the right to claim performance would undermine the obligor's exemption, performance cannot be demanded as long as the impediment exists. ${ }^{70}$ This rule not only applies, for example, to cases of actual impossibility of performance, but also to cases of hardship.

615; Michael Bridge The International Sale of Goods, Law and Practice (2ed, Oxford University Press, Oxford, 2007) para 10.44

64 See Stoll and Gruber in Schlechtriem and Schwenzer (eds), above n 26, Article 74 para 49; ICC Award, 1992, No 7585, CISG-online 105.

65 See also Dionysios Flambouras Comparative Remarks on CISG Article 79 \& PECL Articles 6:111, 8:108 (May 2002) www.cisg.law.pace.edu/cisg/text/peclcomp79.html (last accessed 10 Jul 2008).

66 See Stoll and Gruber in Schlechtriem and Schwenzer (eds), above n 26, Article 79 para 43; Honnold, above n 19, Article 79 para 495.2; Bund, above n 31, 388; Brunner, above n 19, 345-346; Bridge, above n 63, para 12.61; Heuzé, above n 31, 430.

67 See CISG Article 79(5): "Nothing in this article prevents either party from exercising any right other than to claim damages under this Convention."

68 See United Nations Conference on Contracts for the International Sales of Goods, Vienna, 10 March - 11 April 1980, above n 21, 381-382; Schwenzer in Schlechtriem and Schwenzer (eds), above n 18, Article 79 para 52; but see Brunner, above n 19, 362-363.

69 See Magnus in Staudinger, above n 31, Article 79 para 58; Mankowski in Schmidt (ed), above n 26, Article 79 para 8; Peter Huber in Kurt Rebmann and others (eds) Münchener Kommentar zum Bürgerlichen Gesetzbuch (5 ed, CH Beck, Munich, 2008) Article 79 para 29; Salger in Witz, Salger and Lorenz (eds), above n 19, Article 79 para 12.

70 See Schwenzer in Schlechtriem and Schwenzer (eds), above n 18, Article 79 paras 53-54; Magnus in Staudinger, above n 31, Article 79 paras 59-60; Achilles, above n 19, Article 79 para 14. See also Honnold, above n 19, Article 79 para 435.5. 


\section{B Right of Avoidance}

Among the rights that are not affected by an exemption is first and foremost the right to avoid the contract. ${ }^{71}$ However, this right presupposes that the non-performance amounts to a fundamental breach of contract. Whether such a fundamental breach exists largely depends upon the circumstances of the individual case. ${ }^{72}$

Article 25 of the CISG - and likewise Article 7.3.1(2) of the PICC 2004, Article 8:103 of the PECL 1999 and Article III - 3:502(2) of the DCFR 2008 - circumscribes a fundamental breach of contract as one that results in such detriment to the other party as substantially to deprive it of what it is entitled to expect under the contract. One of the central questions thereby is whether it is possible and - having regard to the other party's expectations - just and reasonable that the breach be remedied. ${ }^{73}$ We will return to this question below.

\section{The Obligation to Renegotiate in Cases of Hardship}

In bona fide cases of hardship, Article 6.2.3(1) of the PICC 2004, Article 6:111(2) of the PECL 1999 as well as Article III - 1:110(3)(d) of the DCFR 2008 first state an obligation to renegotiate. The ICC's Hardship Clause 2003 likewise provides that the parties are bound to negotiate alternative contractual terms which reasonably allow for the consequences of the changed circumstances within a reasonable time of the invocation of the Clause. ${ }^{74}$ This duty to renegotiate is seen to be based on a general duty to act in good faith ${ }^{75}$ which is common to many civil law systems. ${ }^{76}$

71 See CISG Article 79(5); Stoll and Gruber in Schlechtriem and Schwenzer (eds), above n 27, Article 79 para 4.; Brunner, above n 22, 366, 367; Honnold, above n 20, Article 79 para 435.1; Achilles, above n 20, Article 79 para 14; Rimke, above n 26, 197, 217; Magnus in Staudinger, above n 32, Article 79 para 55.

72 See Schlechtriem in Schlechtriem and Schwenzer (eds), above n 27, Article 25 para 5: "... any abstract definition [of the fundamental breach] must expect criticism ...". See also Magnus in Staudinger, above n 32, Article 25 para 3; Brunner, above n 43, Article 25 para 8; Oberlandesgericht Stuttgart, 12 Mar 2001, CISG-online 841; CIETAC, 30 Oct 1991, CISG-online 842.

73 See CISG AC Opinion No. 5 The buyer's right to avoid the contract in case of non-conforming goods or documents (Rapporteur: Professor Ingeborg Schwenzer) 7 May 2005, Opinion 3.

74 See ICC Hardship Clause 2003 para (2)(b).

75 See Brunner, above n 19, 480-481; Magnus in Staudinger, above n 31, Article 79 para 24; Brunner, above n 42, Article 79 para 24.

76 The principle of good faith found its way into almost every Civil Law system through the reception of Roman law. See France: Article 1148 CC; Italy: Article 1337 CC; Germany: § 242 BGB; Switzerland: Article 2 ZGB. Common Law systems, however, tend to refrain from accepting good faith as a general principle of contract law: see Michael Bridge "Does Anglo-Canadian Law Need a Doctrine of Good Faith?" (1984) 9 Can Bus LJ 412, 426; Allan Farnsworth "Duties of Good Faith and Fair Dealing under the Unidroit Principles, Relevant International Conventions, and National Laws" (1995) 3 Tul J Int'l \& Comp L 47, 5154. 
Other legal systems do not know such a duty to renegotiate. This is not only true for common law systems, even where they recognise the general principle of hardship or impracticability as section 2-615 of the UCC does, ${ }^{77}$ but also some civil law systems such as Germany where, under the newly enacted section 313 of the BGB, the parties are not bound to renegotiate either. ${ }^{78}$ Although there are some authors favouring such a duty to renegotiate under German law, ${ }^{79}$ the prevailing view follows the clear wording of the provision that does not mention any such duty, but instead allows a party to immediately resort to the court asking for an adaptation of the contract. ${ }^{80}$ Likewise, neither the Italian nor the Dutch Code provisions on hardship ${ }^{81}$ oblige the parties to renegotiate.

Article 79(5) of the CISG, as has already been pointed out, expressly relieves the affected party from damages only. Some authors, however, advocate the idea that under the CISG as well there is a duty to renegotiate based upon Article 7(1) of the CISG, according to which the Convention has to be interpreted with regard to the observance of good faith in international trade. ${ }^{82}$ It has been questioned many times whether Article 7(1) may be applied not only in interpreting the Convention as such, but also in establishing the principle of dealing in good faith among the parties. ${ }^{83}$ Without

77 § 2-615 (a) UCC states that "[d]elay in delivery or non-delivery ... is not a breach of his duty under a contract for sale if performance as agreed has been made impracticable by the occurrence of a contingency ...." For a detailed discussion of the impracticability doctrine in American law, see Treitel, above n 13, para 6-001.

78 See $\S 313$ BGB which does not mention a duty to renegotiate the contract.

79 See Christian Grüneberg in Otto Palandt and others (eds) Bürgerliches Gesetzbuch (67ed, Munich, 2008) § 313 BGB, para 41; Helmut Heinrichs "Vetragsanpassung bei Störung der Geschäftsgrundlage: Eine Skizze der Anspruchslösung des § 313 BGB" in Stephan Lorenz and others (eds) Festschrift für Andreas Heldrich zum 70. Geburtstag (CH Beck, Munich, 2005) 183, 195; Karl Riesenhuber "Vertragsanpassung wegen Geschäftsgrundlagenstörung - Dogmatik, Gestaltung und Vergleich" (2004) 59 Betriebs-Berater 2697, 2698.

80 See Peter Schlechtriem "The German Act to Modernize the Law of Obligations in the Context of Common Principles and Structures of the Law of Obligations in Europe" [2002] Oxford U Comparative L Forum 2 ouclf.iuscomp.org (last accessed 22 Jul 2008); Unberath in Bamberger and Roth (eds), above n 11, § 313 para 85; Barbara Dauner-Lieb and Wolfgang Dötsch "Prozessuale Fragen rund um § 313 BGB" [2003] NJW 921, 922.

81 See Articles 1467-1469 Italian CC (onerosità); Articles 6:258 and 6:260 Dutch BW; Article 451 of the Civil Code of the Russian Federation. See also Klaus Berger "Renegotiation and Adaptation of International Investment Contracts: The Role of the Contract Drafters and Arbitrators" (2003) 36 Vand J Transnat'l L 1347, 1356. For further references, see Brunner, above n 19, 480.

82 CISG AC Opinion No 7, above n 24, Comment para 40; ICC Award, Mar 1999, No 5953, Clunet 1990, 1056.

83 See Schlechtriem in Schlechtriem and Schwenzer (eds), above n 27, Article 7 para 7; Farnsworth, above $n$ 76, 56. 
having to decide this dispute the question of any duty to renegotiate can be answered in the negative.

In the first place, renegotiation - as negotiation - has to be based on willingness and trust. Constructive and cooperative renegotiation cannot be forced upon the parties by coercion. ${ }^{84}$ Furthermore, lacking any means of specific enforcement, the duty to renegotiate amounts to nothing more than a farce. The duty to negotiate would gain importance only if breaching it were sanctioned. Indeed, this is envisaged by Article 6:111(3)(c) of the PECL 1999. Accordingly, the court may award damages for the loss suffered through a party refusing to negotiate or breaking off negotiations contrary to good faith and fair dealing. However, it is certainly not advisable to state such a liability in damages. Cases of hardship involve such complex fact situations and evaluations that it can hardly be determined whether a party refusing or breaking off negotiations acted in bad faith. In addition, international trade regularly calls for promptness and legal certainty, which militate against lengthy negotiations. Clear cases of bad faith may be taken into account upon allocating the costs of proceedings. ${ }^{85}$

To sum up, in cases of hardship a duty to renegotiate should not be advocated. This, however, does not preclude that an offer by one party to adapt the contract to the changed circumstances becomes relevant when dealing with the possible respective remedies of the parties.

\section{Adaptation of the Contract and Avoidance}

Under some civil law legal systems, in cases of hardship, the court is primarily called upon to adapt the contract to the changed circumstances. ${ }^{86}$ Avoidance is allowed only as a remedy of last resort if an adaptation of the contractual terms is either not possible or not just and reasonable having regard to the respective interests of the parties. ${ }^{87}$ Article 6.2.3(4) of the PICC 2004, Article 6:111(3) of the PECL 1999 as well as Article III - 1:110(2)(b) of the DCFR 2008 also follow this approach. On the other hand, Article 1467 of the Italian Codice Civile as well as the ICC Hardship Clause 2003 take a different stand: the party invoking hardship is entitled to an avoidance of the contract; an adaptation of the contract is not contemplated. ${ }^{88}$

84 See Günter Roth in Wolfgang Krüger (ed) Münchener Kommentar zum Bürgerlichen Gesetzbuch (5ed, CH Beck, Munich, 2007) § 313 BGB, para 93; Dauner-Lieb and Dötsch, above n 81, 925.

85 See Brunner, above n 19, 483.

86 See § 313(1) BGB. In Switzerland see Swiss Federal Supreme Court (Bundesgericht) on clausula rebus sic stantibus, BGE 107 II 343, 348.

87 See § 313(3) BGB.

88 The ICC Hardship Clause 2003 states in para 3 that "... the party invoking this Clause is entitled to termination of the contract." 
If one recognises hardship as an impediment under Article 79 of the CISG, it is questionable whether an adaptation of the contract is possible. ${ }^{89}$ It can hardly be conceived that there is a gap in the CISG that can be filled by giving the court or tribunal the power to adapt the contract to the changed circumstances. Therefore, it has been proposed to rely on Article 6.2.3(4) of the PICC 2004 as constituting an international usage in the sense of Article 9(2) of the CISG in order to reach the desirable result of adaptation. ${ }^{90}$ This doctrinal method does not seem to be necessary, however. The usual remedy mechanism under the CISG in combination with the duty to mitigate as a general principle ${ }^{91}$ may yield satisfactory and flexible results in practice. This may be demonstrated by the hypothetical case where the acquisition costs for the seller have tripled, thus giving rise to a plea of hardship. Upon the seller informing the buyer that it is not able to perform the contract because of this event, there appear to be two possible scenarios.

Under the first scenario, the seller suggests delivering the goods if the buyer is willing to pay a higher purchase price. If the buyer consents, the contract is accordingly adapted. If the buyer does not consent, and the seller repudiates the contract, based on its original terms, on the ground of hardship, the buyer in turn will sue the seller for specific performance or, most probably, for damages. The court or tribunal will then find that the seller is released from its obligations due to hardship. If the seller wants to go through with the contract, albeit on different terms, it will initiate a counter-claim seeking performance or damages for wrongful repudiation on the part of the buyer. The buyer will then rely on avoidance because of a fundamental breach. Now, the court or tribunal has to decide whether the fact that the seller was willing to deliver the goods, but on different terms, amounted to a fundamental breach of contract giving the buyer the right to avoid the contract. The court here will have to consider whether it would have been just and reasonable for the buyer, in the circumstances of the given case, to accept the different terms offered by the seller. If it finds that the buyer should have consented to an adaptation on the basis of good faith, it will find for the seller.

Turning to the second scenario, the buyer offers to pay a higher price whereas the seller wants to get out of the contract. Under these circumstances again, probably the buyer will claim either specific performance or damages. The court or tribunal now has to determine whether, having regard to the different contract terms offered by the buyer, hardship can still be held to exist. If not, the seller is not released from its obligation to perform or to pay damages.

Thus, in both scenarios, results can be reached similar to those in legal systems that expressly provide for the power of the court or tribunal to adapt the contract to the changed conditions.

89 But see CISG AC Opinion No 7, above n 24, Comment para 40.

90 See Schlechtriem, above n 19, para 291.

91 See Ingeborg Schwenzer and Simon Manner "The Pot Calling the Kettle Black: The Impact of the NonBreaching Party's (Non) Behaviour on its CISG-Remedies" in Camilla Andersen and Ulrich Schroeter (eds) Sharing International Commercial Law Across National Boundaries - Festschrift for Albert H Kritzer (Wildy, Simmonds \& Hill, London, 2008) 470, 480. 
Although there is no explicit duty to renegotiate under the CISG, there certainly is a duty to mitigate damages according to Article 77 . This duty to mitigate may well require the aggrieved party to strike a deal even with the contract breaching party and, a fortiori, in cases where unforeseen circumstances make performance excessively onerous for one party. ${ }^{92}$

Although this mechanism seems to be especially warranted in cases of hardship, it might also come into play in cases of other impediments under Article 79 of the CISG. Thus, where the seller has sold specific goods that were destroyed after the formation of the contract, it may well be the case that substitute goods exist, serving the buyer's interests just as well as the original ones. If the seller offers these goods as a "cure", the buyer may well be obliged to accept them as no fundamental breach of contract can be ascertained in this case.

\section{CONCLUSION}

Whereas many systems - especially, in recent times, PICC 2004, PECL 1999 and DCFR 2008 clearly distinguish between force majeure and hardship under the CISG, both situations have to be dealt with under the same provision, namely Article 79. And rightly so. All too often, drawing the line between force majeure and hardship is not possible. The days of the old Roman notion of "impossibility" are gone; most subsequent events do not render performance impossible and, thus, do not constitute a veritable impediment in the sense of Article 79; they just render performance more or less onerous for the obligor. Consequently, it seems preferable to deal with both situations under the same heading with the same prerequisites and the same consequences.

It has been shown, under the remedies mechanism of the CISG, that there is enough flexibility to reach just and equitable results, on the one hand, that guarantee legal certainty and, on the other hand, that contribute to implementing good faith and fair dealing in international sales law. Thus, the very minimalism of the CISG on questions of hardship facilitates solutions that are well adjusted to the everyday needs of globalised international trade.

92 Ibid, 470-486 
